\title{
Главы малых российских городов: лидерство и эффективность управления ${ }^{1}$
}

\author{
А.Е. ЧИРИКОВА*, В.Г. ЛЕДЯЕВ**
}

\begin{abstract}
*Алла Евгеньевна Чирикова - доктор социологических наук, главный научный сотрудник, Институт социологии Федерального научно-исследовательского социологического центра РАН. Адрес: 117218, Москва, ул. Кржижановского, д. 24/35, корп. 5. E-mail: chirikova_a@mail.ru

**Валерий Георгиевич Ледяев - доктор философских наук, профессор, факультет социальных наук, Национальный исследовательский университет «Высшая школа экономики». Адрес: 101000, Москва, ул. Мясницкая, д. 20. E-mail: vledyaev@hse.ru
\end{abstract}

Цитирование: Чирикова А.Е., Ледяев В.Г. (2021) Главы малых российских городов: лидерство и эффективность управления // Мир России. Т. 30. № 1. С. 29-48. DOI: $10.17323 / 1811-038 X-2021-30-1-29-48$

В статье представлены результать эмпирического исследования лидерства и власти в трех мальх городах Пермского края и Ивановской области, проведенного в 2011-2015 и 2018-2019 годах. Исследование показало, что, несмотря на политику централизации, проводимую федеральным центром и выстроенную вертикаль власти, сохраняется довольно широкая вариативность паттернов власти и лидерства, обусловленная главным образом персональным фактором. Нами были обнаружены и моноцентрические конфигураџฺи власти (четко выделялся один локальный лидер, явно возвышавшийся над другими элитныли фигурами), и полицентричная структура власти (альянсы и/или соперничество нескольких фигур с сопоставимыми ресурсами власти и влияния). Смена фигур во власти может существенно скорректировать не только стиль управления и характер внутриэлитных взаимоотношений, но и властную иерархию.

Лидерство, как и другие сочиильные явления, находится в процессе постоянного изменения. Исследование продемонстрировало динамику лидерства глав не только при смене ключевых фигур, но и в результате эволючии лидеров, изменений в их установках, формах и методах взаимодействия с окружающими. На динамику власти и лидерства наибольшее влияние оказывают институциональные изменения в структуре муниципальной власти, смена руководства регионами, персональный и ситуативный факторы. Результаты исследования подтвердили предположение о том, что не всегда руководители

1 Исследование было выполнено при финансовой поддержке РФФИ, исследовательский проект № 20-011-31192 опн. 
исполнительной власти являются наиболее влиятельными фигурами в городском сообществе, хотя они обладают наиболее значимыми формальными ресурсами власти. Не все главы администращий в изученных городах были действительными лидерами локальных сообществ, поскольку не все обладали высоким авторитетом, сильной командой и выстроенными отношениями с руководством региона. В тех случаях, когда персонального ресурса явно не хватало, вакуум власти заполнялся иньми силами - либо другими локальныли акторами, либо региональными властями, усиливавшими контроль для поддержания порядка и управляемости территорией.

Исследование показало, что лидер, хотя и не способен полностью переломить негативные тенденции, обусловленные внешними факторами, может смягчить их последствия. Ухудиение сочиально-экономической ситуации в мальх городах может быть приостановлено в том случае, если глава города и другие представители элитного пула способны взять на себя лидерские функции и использовать их для достижения общего блага. В периоды кризисов и институциональных реформ роль руководителей возрастает, поэтому именно при возникновении трудностей формируется запрос на лидерство.

Ключевые слова: глава города, власть, лидерство, малые города, локальная политика, эффективность управления

В последнее десятилетие изучение власти, городских режимов и локальной политики становится быстро развивающимся направлением исследования в отечественной политической науке и социологии [Сельцер 2017; Чирикова, Ледяев 2017; Шкель 2017; Красильщиков, Трочикая 2018; Панов 2019; Пустовойт 2019]. Академический дискурс охватывает широкий спектр проблем, которые так или иначе касаются роли наиболее влиятельных акторов - лидеров и руководителей локальных сообществ.

Политическая власть обычно имеет институциональные основания, но обязательно персонифицирована. Власть осуществляют конкретные люди - как носители формальных полномочий, так и обладающие солидным набором различных персональных/неформальных ресурсов, поэтому феномен власти тесно переплетается с феноменом лидерства. Именно этот аспект властных отношений - власть наиболее влиятельных акторов (лидеров) городских сообществ - и представлен в данной статье.

На основе эмпирического исследования в малых городах России мы попытаемся представить некоторые существенные аспекты лидерства и власти в локальных сообществах, показать, кто и как реально управляет городом, какие факторы и ресурсы играют ключевую роль во властных практиках и почему конфигурации наиболее влиятельных акторов, стили лидерства и паттерны власти в разных городах существенно различаются.

\section{Лидерство в локальном сообществе: проблемное поле}

За примерно вековую историю изучения власти были проведены сотни исследований, обобщен большой эмпирический материал, позволивший расширить и углубить знание многих важнейших аспектов общественно-политической жизни 
[Harding 2009; Ледяев 2012]. С самого начала исследований в этой области ученых интересовали конкретные люди, лидеры и руководители локальных сообществ - те, кто играет ключевые роли в политической жизни города, обладает высоким авторитетом и ресурсами власти, позволяющими направлять деятельность других людей ${ }^{2}$.

Однако само по себе обладание формальными позициями и ресурсами власти, как показывает практика, в т. ч. в пространстве городской политики, не гарантирует власти и влияния. Это обусловлено тем, что ресурсы власти не вполне адекватно используются их обладателями или же они оказываются неэффективными в определенных условиях, что хорошо известно теоретикам власти [Ледяев 2001; Wrong 2002]. Лидерство обычно опирается не только на формальные, но и на неформальные ресурсы. История и практика дают много примеров и кейсов сильных руководителей, действовавших без формальных полномочий, и отсутствия лидерства у обладателей высокого статуса, при этом не все влиятельные люди являются лидерами. К последним обычно не относятся те, чья власть опирается исключительно на силовые ресурсы и инструменты принуждения. С этой точки зрения лидерство можно считать формой власти («А может заставить Б делать то, что Б в ином случае не стал бы делать»), но не любой власти, а лишь той, которая обусловлена способностью лидера мотивировать своих последователей с помощью авторитета, побуждения, убеждения, моральных призывов [Burns 1978; 't Hart, Rhodes 2014].

Политическое лидерство в городских сообществах является важным аспектом городской политики. Главный фокус исследований лидерства направлен на то, как оно влияет на ситуацию в городе [Stone 1995; Greasley, Stoker 2009; Copus, Leach 2014]. Кроме того, исследователей интересует и ряд других важных факторов политического лидерства. В нашем исследовании эмпирический анализ фокусируется на следующих проблемах:

1. Персональный ресурс лидеров. Все теории лидерства в большей или меньшей степени учитывают роль личностных факторов лидерства - совокупности знаний, умений, навыков и установок, обусловливающих их потенциал влияния. Одной из первых теорий лидерства, сфокусировавшей внимание на персональных качествах, была так называемая теория черт [Stogdill 1974], согласно которой именно набор определенных качеств делал людей успешными лидерами. Сегодня теория не выглядит убедительной, поскольку просто обладание определенным набором черт, как свидетельствует исторический опыт, не гарантирует достижения успеха в разных контекстах. Однако психологический портрет лидера, его профессиональный ресурс, структура мотивации и установки являются важными для понимания всех форм лидерства.

2. Лидеры и их последователи. Лидеры, хотя и занимают особое положение в социуме, не могут реализовать свой лидерский потенциал без других акторов: они и их последователи - это партнеры, которые работают на достижение общих целей. Лидер так или иначе всегда находится в связке со своими последователями и должен учитывать их потребности, интересы, желания и мотивацию. Поэтому

\footnotetext{
2 Вслед за классиком лидерства М. Бернсом мы понимаем его как реципрокный процесс мобилизации различных экономических, политических и других ресурсов для реализации целей лидеров и их последователей [Burns 1978]. Политический лидер - это человек, который наиболее полно отражает и защищает интересы определенной социальной группы, обладает совокупностью качеств, необходимых политическому деятелю, стремится и способен консолидировать усилия окружающих и активно воздействовать на этот процесс для достижения обозначенных и выдвинутых им целей.
} 
лидерство рассматривается не как некое свойство руководителя, обусловленное его ресурсами и характеристиками, а как интеракция между лидерами и их последователями. В контексте локального политического пространства особую роль в группе последователей играют те, кто считается членами команды руководителя: его ближайшее окружение, непосредственные подчиненные, группа поддержки. Численность команд может существенно варьироваться, но ядро команды обычно составляют 5-7 человек.

3. Степень автономии локальных лидеров и их взаимодействие с региональньлми и федеральньми структурами государственного управления. Будучи лидерами/руководителями в своих локальных сообществах, они одновременно находятся в системе субординации и подчинения акторам более высоких уровней. В России на сегодняшний день региональные элиты, не говоря уже об акторах федерального уровня, имеют широкий спектр возможностей для того, чтобы добиться субординации в отношениях с муниципалитетами и их руководителями. Естественно, что, обладая различными ресурсами влияния на локальных лидеров, региональные власти (представители центральной власти редко испытывают необходимость спускаться на местный уровень) видят в локальных лидерах прежде всего проводников своей политики. Однако достраивание вертикали власти до нижних (муниципальных) этажей не означает, что локальные акторы обязательно оказываются в проигрыше. В авторитарных режимах, как отмечает Б. Геддес [Geddes 1994, pp. 193-194], система опирается не только на контроль, но и возможности правителей перераспределять ресурсы и привилегии. Конвергенция целей авторитарных руководителей и подчиненных акторов подразумевает, что первые должны обеспечить местные элиты властью, статусом, благосостоянием, карьерными перспективами, чтобы эффективно реализовывать цели режима.

4. Эффективность выполнения лидерами своих функций. Оценка результатов деятельности руководителей представляет серьезные трудности. Всегда сложно определить, в какой степени успешность работы обусловлена его собственными усилиями и умениями, а не является следствием тех или иных благоприятных обстоятельств. Но даже если не учитывать эту проблему, то остается неясным, какие именно критерии успеха следует считать определяющими. Этим критерием может быть длительность пребывания в должности или итоговая оценка карьеры («что напишут на надгробной плите») ['t Hart, Rhodes 2014]. Имели место и попытки описать некоторый набор относительно объективных показателей: например, Харт предлагает три группы взаимосвязанных и взаимовлияющих критериев (так называемый оценочный треугольник): (1) эффективное решение проблем («умное лидерство»); (2) поддержка избирателей и ключевых акторов («поддерживаемое лидерство»); (3) выполнение обязательств («ответственное лидерство») ['t Hart 2014]. В той или иной степени приведенные критерии оценки могут быть использованы для анализа лидерства в городской политике.

Эти и некоторые другие темы обозначили проблемное поле нашего исследования и его структуру. В данной статье мы рассматриваем наиболее влиятельных акторов (лидеров) в каждом локальном сообществе, их источники, формальные и неформальные ресурсы власти, сформированность/несформированность команд глав городов, эффективность лидерства и обусловливающие их факторы. Особое внимание будет уделено изменениям, произошедшим в городах между первым и вторым этапами исследования. 
Цель исследования - проанализировать существующие практики властвования в малых городах, оценить лидерские качества глав городов и эффективность их деятельности. В ходе исследования нами будут проверяться следующие гипотезы:

1. Главы городов с лидерским потенциалом и сформированной командой более эффективны, чем главы, не обладающие лидерским потенциалом и командой последователей. Поэтому смена персоналий в муниципальной власти может приводить к реальным изменениям в политическом, социальном и экономическом пространстве малого города, особенно в условиях кризиса.

2. Глава города, даже обладающий качествами лидера, не способен полностью переломить негативные тенденции, обусловленные внешними факторами, но может смягчить их последствия.

Исследование проводилось в два этапа - в 2011-2015 гг. ${ }^{3}$ и 2018-2020 гг. в трех малых городах Пермского края и Ивановской области. Основной эмпирический материал был получен в ходе глубинных интервью, подпадающих под категорию элитных интервью [Hlynsdottir 2016, p. 813]. Среди интервьюируемых были региональные руководители и эксперты, представители руководства законодательной и исполнительной власти во всех локальных сообществах, депутаты местных представительных учреждений, чиновники и работники аппарата исполнительной власти и легислатур, руководители местных газет и телевидения, предприниматели, бизнесмены и руководители предприятий, лидеры и активисты местных партийных и общественных организаций. Всего было проведено 97 интервью $\left(50\right.$ - на первом этапе, 47 - на втором $\left.{ }^{4}\right)$.

\section{Власть в городе X: от лидерства к «удаленному управлению»}

Во время проведения первого этапа исследования наиболее влиятельным актором и безусловным лидером городского сообщества был глава городской администрации. Он руководил городом в течение восьми лет, затем пошел на повышение в региональные структуры власти, но постоянно держал руку на пульсе городского управления.

В период проведения второго этапа исследования во главе администрации города X оказался другой человек, но бывший глава по-прежнему воспринимался

\footnotetext{
3 Результаты первого этапа исследования уже описаны нами ранее [Чирикова, Ледяев, Сельиер 2014; Чирикова, Ледяев 2017].

4 Разумеется, мы понимаем, что любые оценки действующих акторов субъективны. Мы также осознаем трудности интервьюирования влиятельных фигур - политиков, чиновников, бизнесменов, руководителей организаций в силу того, что они часто склонны вести себя настороженно, закрыто, ограничиваться штампами. Однако эти трудности можно, по крайней мере, отчасти преодолеть с помощью профессионального опыта интервьюера и хорошего владения техникой проведения интервью. Нами использовался достаточно широкий набор специальных технологий, позволяющих повысить надежность получаемой информации: построение системы провоцирующих вопросов, позволяющих перепроверять сообщаемую информацию, установление особого эмоционального контакта с респондентом, повышенное внимание к содержанию разговора, позволяющее снизить уровень контроля говорящего, привлечение к интервью фигур, непосредственно включенных в политические процессы и одновременно воспринимающих их как обычную повседневную практику и др.

Мы знаем, что метод сравнения кейсов в силу их небольшого числа имеет существенные ограничения и позволяет делать только частичные генерализации. Однако он, как подчеркивает А. Лейпхарт, полезен как первый шаг [Lijphart 1975, р. 172], поскольку помогает очертить проблематику, сформулировать гипотезы, настроить инструментарий, выделить проблемы, трудности исследования и сформулировать предварительные выводы.
} 
большинством наших респондентов как наиболее влиятельный актор в городском политическом пространстве - и в тот период, когда он работал в правительстве региона, и даже когда он ушел с этого поста. На протяжении более десяти лет этот человек во многом определял политику в городе, однако характер и форма его лидерства в течение этого срока претерпели существенные изменения.

Он пришел к власти, победив на выборах, и так получилось, что он оказался единственным руководителем, избранным населением: победа досталась ему в острой борьбе с бывшим мэром, весьма авторитетной фигурой в городе X. Объясняя его первенство во властной иерархии, информанты исходили прежде всего из широкого набора формальных ресурсов, которыми он обладал. Однако не только они обусловливали его лидерство. Важнейший дополнительный ресурс главы администрации заключался в том, что именно он более других локальных акторов был связан с влиятельными персонами регионального и федерального уровней. Кроме того, в то время он имел реальные возможности использовать в качестве инструментов своего влияния структуры, не находящиеся в сфере его подчинения: пожарные инспекции, санитарные службы, энергетические организации и др. Наконец, высокий потенциал власти главы администрации опирался на его высокий авторитет у части местной элиты, своей команды (частично) и населения. Он активно и успешно занимался благоустройством города, что не могло пройти незамеченным.

Тем не менее оценки его деятельности на посту главы администрации города были довольно противоречивыми, что особенно проявилось на втором этапе исследования. Одни респонденты полагали, что его пребывание у власти было полезным для города: «Период правления господина "серого кардинала"5 был не самым худшим. Сделано было много в плане развития сочиальной сферы и инфраструктуры города. Для города это были знаковые вещи. Потом (на втором сроке), к сожалению, все пошло по наклонной», - убежден его первый заместитель. Другие были уверены в том, что на самом деле он просто воспользовался плодами деятельности своего предшественника: «Он жил не на своем багаже, а на багаже мэра, который умел мыслить стратегически. Выборы их разделили, поставили по разные стороны баррикад», - считала местная журналистка.

Следует отметить, что тон высказываний и оценки его деятельности на посту главы администрации города $\mathrm{X}$ в период его второго срока пребывания в должности становились, в отличие от первого срока, менее позитивными. Во многом это было связано с изменением состава его команды. Причиной тому стали затеянная им реорганизация команды, а также нежелание некоторых ее членов мириться с серыми схемами, которые стали использоваться им намного чаще. В результате команду покинули некоторые ключевые фигуры, благодаря которым ранее он в целом успешно осуществлял управление городом. Другой причиной снижения эффективности его лидерства явилось усиление меркантильных (корыстных) мотивов, проявившееся в продвижении своей фирмы, выгодных личных связей с бизнесом и т. п. «Для бывшего главы нашего города политика - это бизнес, это болезнь. Чем больше человек зарабатывает денег, тем больше их хочется заработать еще больще», - отмечал начальник департамента внутренней политики района.

Переход на работу в региональные структуры власти оказался для него весьма своевременным в силу нарастания кризисных явлений, недовольства значи-

\footnotetext{
5 Так некоторые респонденты называли бывшего главу во время проведения второго этапа исследования.
} 
тельной части локальной элиты и трудностей в управлении своей командой в частности и городом в целом. Но, даже находясь формально за пределами городской политики, бывший мэр продолжал весьма активно в ней участвовать, оказывая влияние на многие ключевые фигуры в локальном пространстве города Х. Этому способствовала и занимаемая им должность министра территориального развития, со временем трансформировавшаяся в пост первого вице-премьера правительства.

Вновь назначенный глава города был креатурой бывшего главы, оказавшегося на руководящей должности в крае. Наши респонденты на момент проведения второго этапа исследования воспринимали его в связке именно с ним; они прекрасно понимали, кто в этой связке главный, и были уверены в том, что бывший глава фактически давал прямые указания новому главе, а тот их исполнял. «"Серый кардинал" его инструктирует. Он говорит ему, что надо сказать и что сделать». Личная преданность нового главы и возможность его контролировать стали главными причинами продвижения этого человека во власть. Других серьезных аргументов в пользу назначения нового главы на должность наши респонденты не нашли.

В отличие от неоднозначного отношения к бывшему главе, ставшему со временем «серым кардиналом», отношение к новому руководителю было практически единодушно отрицательным; фактически его не поддерживала ни одна из фракций локальной элиты. Претензий к нему как к руководителю городской администрации было много, и они обусловлены тем, что ему явно не хватало личного ресурса для успешной работы. Уничижительные оценки его возможностей, сделанные нашими респондентами, весьма красноречивы: «К сожалению, управление городом - это не уровень главы. Не вырос он до этого уровня. У него достаточно небольшой кругозор. Это человек от сохи» (бывший мэр); «Он не лидер. На уровне столярно-слесарной бригады он был бы наиболее эффективным» (предприниматель, депутат городской думы). По сути, новый глава воспринимался элитой как плохая копия бывшего мэра. Пытаясь действовать в том же ключе, что и бывший глава, но не обладая его ресурсом, он не только не привнес ничего нового в городскую повестку, но и в целом снизил качество управления городом. Некоторые респонденты в своих интервью называли его «антилидером».

Бывший глава, формально находясь за пределами городского политического пространства, фактически оставался едва ли не наиболее влиятельным актором в городе на фоне нового слабого руководителя. Для обозначения сложившейся ситуации, как нам представляется, вполне подходит термин «удаленное управление»: стратегические решения новый глава принимал исключительно по согласованию с «серым кардиналом». «Несмотря на то, что он глава, все равно на сегодня им управляет “серый кардинал”" ${ }^{6}$. На вопрос о том, чем обусловлено такое внимание бывшего главы к городским делам, представители местной элиты давали разные ответы, но основной - следующий: оставшись без работы в крае, «серый кардинал» хочет сохранить и укрепить свою власть в городе ради извлечения личной выгоды, поскольку в городе у него по-прежнему имеются источники дохода (фирмы, рынок), требующие контроля.

\footnotetext{
6 «Удаленное управление» продолжилось и после того, как «серый кардинал» потерял свою высокую должность в краевой администрации, а против него было возбуждено уголовное дело. После снятия с должности он возвратился в город и начал управлять им через своего ставленника, надеясь вернуться во власть и стать во главе объединенной территории, которую планировалось создать в результате слияния городской и районной структур власти; эту идею он активно продвигал в период работы в правительстве края.
} 
Однако вероятность как второго пришествия бывшего главы на руководящую должность в городе, так и продолжение «удаленного управления», как полагали наши респонденты, невелика. Спустя два месяца после окончания исследования ожидания элит сбылись: слабый глава, креатура «серого кардинала», с подачи губернатора покинул свой пост. Временным главой исполнительной власти в городе стал глава района, поставленный на должность для решения двух главных задач: слияния городской и региональной властей и формирования городского округа.

Полученные эмпирические результаты и их последующий анализ позволяют сделать как минимум два важных вывода. Во-первых, даже в том случае, если глава обладает выраженным лидерским потенциалом, его действия, направленные на извлечение личной выгоды, приводят к тому, что он теряет рычаги влияния на локальную элиту, и прежде всего на свою команду, что со временем сказывается на эффективности управления городом. Таким образом, не всякое лидерство приводит к росту эффективности: оно помогает улучшить ситуацию в городе, когда лидерский потенциал главы направлен не на извлечение личной выгоды, а на общественное благо. Во-вторых, отсутствие сильного лидера в городе, даже при активном «кукловоде», ухудшает политическую, социальную и экономическую ситуацию настолько, что локальные элиты начинают воспринимать ее как безысходную. Если слабый глава просто выполняет указания «серого кардинала», который руководствуется исключительно желанием реализовать собственные интересы, то позитивные изменения вряд ли возможны, и в этой ситуации без прихода нового лидера город обречен на дальнейшую деградацию.

\section{Город Y: от старой - к новой триаде лидеров}

Город Y - моногород, и данное обстоятельство существенно повлияло на специфику и особенности городской политики, пул лидеров, расклад сил и взаимоотношения между ними.

В период проведения первого этапа исследования мы обнаружили три наиболее влиятельных актора, обладающих примерно равными властными ресурсами: директор предприятия; глава города - руководитель местного совета; глава администрации района. Наиболее сильным политиком считался глава города, умевший разговаривать с населением и манипулировавший только что назначенным ситименеджером: «Глава города изощреннее любых других политиков в городе, у него больще опыта. У него нет речи, но зато есть чутье и некая харизма. Он неизвестно что болтает, но его народ при этом слушает, он свойский», - так характеризовал главу города режиссер местного телевидения.

На главу города в то время активно работала его команда, отношения в которой были вполне традиционными, строились на принципах полного подчинения; они складывались в течение длительного времени, и никто из членов команды не был способен их изменить. Ситуацию с командой главы города наиболее емко описал известный в городе журналист: «Если чиновники главы города начнут играть свою игру, то глава их сразу уволит».

Примерно равным потенциалом влияния в локальном пространстве $\mathrm{Y}$ в то время обладало руководство районной администрации, но конфигурация его 
ресурсов была иная: у руководства было больше, по сравнению с городом, бюджетных ресурсов, но при этом глава районной администрации не смог стать наиболее влиятельным политиком в локальном сообществе. Главные причины этого наши респонденты видели в его личных качествах и недостатке профессиональных компетенций, что фактически привело к переходу многих его функций к заместителям, которые обладали большими персональными ресурсами. Активность замов и их профессионализм определенным образом компенсировали недостаток личностного ресурса главы, и в то время они вместе образовали одну из трех вершин власти.

Третьим влиятельным актором в городе Ү в период проведения первого этапа исследования было руководство завода (типичный топ-актор в моногороде). Тогда мы, опираясь на мнения респондентов, поставили руководство завода ${ }^{7}$ на первое место в сложившемся «треугольнике власти», в котором лидерство смещалось от одной вершины к другой. Основные аргументы, используемые экспертами в пользу данной конфигурации, исходили из доминирующей роли завода в экономической и социальной сферах жизни города, где директор завода был не только экономическим, но и политическим игроком, оказывая определяющее влияние на политические процессы в городе.

Таким образом, в период проведения первого этапа исследования в городе Y сложился своеобразный триумвират наиболее влиятельных акторов, находящихся в динамическом равновесии при относительном паритете имеющихся у них ресурсов. Несмотря на это, никого из них нельзя было назвать полноценным лидером городского пространства из-за отсутствия стратегических целей, а их политическое руководство осуществлялось исходя из сиюминутных интересов каждого члена триумвирата.

Спустя 7-8 лет мы вновь обнаружили некий триумвират наиболее влиятельных фигур в локальном политическом пространстве; но его состав, связи и отношения претерпели существенные изменения, вызванные несколькими обстоятельствами. Во-первых, на расклад сил повлияла реформа структуры муниципальной власти: за полгода до второго этапа нашего исследования городское и сельские поселения, ранее входившие в состав муниципального района Y, были преобразованы в новое муниципальное образование «городской округ Ү». В этом случае сама собой отпала фигура руководителя районной администрации; и если ранее между ветвями власти всегда имелись трения и их представители часто сталкивались в борьбе за определенные позиции в локальной структуре власти, то теперь серьезное политическое соревнование в городе отсутствует.

Во время проведения второго этапа исследования глава городского округа, председатель городской думы и поддерживающие их значимые фигуры полностью контролировали ситуацию; при этом оппозиция, которая стремилась бы изменить сложившуюся ситуацию, не была выявлена, а все те, кто потенциально мог бы составить конкуренцию нынешнему руководству города, фактически приняли их лидерство. Об этом говорили многие респонденты, видя в этом и плюсы, и минусы. Наиболее ярко выразился наш эксперт, ранее активно участвовавший в местных политических баталиях: «Раньше было против кого бороться - против меня. Победили. Способы оставим в стороне. Сейчас бороться не с кем».

\footnotetext{
7 В тот период под руководством завода мы фактически имели в виду его директора. Однако, как выяснилось уже в ходе проведения второго этапа исследования, важную роль, по-видимому, вполне сопоставимую с ролью директора завода, уже тогда играл будущий глава городской думы, ныне один из двух самых влиятельных людей в Ү.
} 
Во-вторых, изменилась степень включенности руководства градообразующего предприятия в городскую политику, а его влияние на социально-политические процессы стало более опосредованным. «Завод сегодня не является экономическим и политическим лидером. Политическое влияние завода на территорию резко упало, и это главная трансформация, которая произошла», - констатировал глава городского округа. Снижение роли завода было обусловлено как объективными обстоятельствами, связанными с падением производства и сокращением численности работников, так и субъективным фактором - собственники завода взяли курс на снижение уровня участия завода в локальной политике, требуя от городской власти только поддержания социальной стабильности: «Это бизнес, который исходит из своих интересов». Председатель Думы признавался: «Завод от меня ничего не хочет. Собственник хочет от меня социального спокойствия». Таким образом, из числа наиболее влиятельных акторов выпала фигура директора завода, но тем не менее позиции завода в локальном политическом пространстве в целом сохранились, поскольку его интересы были представлены влиятельным актором, которого некоторые респонденты называли «серым кардиналом» или «теневым лидером» локального сообщества, в лице председателя городской думы городского округа.

В-третьих, ключевой пост главы городского округа занял человек с серьезным персональным ресурсом, опытом и связями, успешный бизнесмен, ранее возглавлявший городское поселение, потом муниципальный район. Подавляющее большинство наших респондентов относились к нему в целом позитивно, достаточно высоко оценивая его профессиональные, человеческие и лидерские качества. Он «умеет быть и лидером, и исполнителем - у него это четко получается»; обладает мотивачией, работоспособностью, инстинктом самосохранения («он же политик»), гибкостью. Он, безусловно, сильнее «старых лидеров», которые сегодня городской округ «не потянули бы» (министр территориального развития).

В то же время, как и у любого руководителя, у главы округа были проблемы, самая важная из которых - команда. Источник этой проблемы, как и в других малых городах, - отсутствие достаточного количества квалифицированных кадров, но и в этих обстоятельствах, как полагал председатель городской думы, главе следовало бы более решительно избавляться от некоторых членов своей команды. «Ясно, кого надо гнать, но он не гонит». Причина, по мнению информанта, заключалась в том, что «он [слишком] сильно доверяет своему окружению и слишком к ним привязан». Ошибки в формировании команды снизили его лидерский потенциал, однако преимущества его перед главой восьмилетней давности в оценках элит не подвергались сомнению. Этот и другие недостатки не мешали главе округа оставаться лидером (одним из лидеров) городского сообщества, и, по мнению представителей городской элиты и региональных чиновников, в целом он успешно руководил городом.

B-четвертых, одной из наиболее влиятельных фигур (а некоторые наши респонденты считали его самой влиятельной фигурой) в локальном пространстве $\mathrm{Y}$ являлся руководитель местной легислатуры, одновременно возглавлявший местное отделение партии «Единая Россия». Он представлял политические интересы завода («Директор завода просто спокоен, потому что я там»); поэтому руководство завода, хотя и уходило от активного публичного участия в городской политике, «с точки зрения принятия решений держало руку на пульсе». Председатель городской думы обладал незаурядными деловыми и персональными качествами, для 
которого политика - и призвание, и профессия, он «сделал фантастическую теневую карьеру». Наиболее очевидным индикатором лидерства главы городской думы являлась его определяющая роль в назначении на ключевые посты в муниципальных структурах («он определил каждому свою роль», бывший депутат городской думы). И руководитель округа, и его заместитель, и другие важные фигуры в администрации, и основная масса депутатов - его протеже («так получалось, что всеми этими процессами занимался я»). Это признает и нынешний глава городского округа («именно он поддержал меня со стороны завода»). Фактически председатель городской думы сам сформировал ее состав («я всех ux выставлял»). Даже глава городского округа, фигура, наиболее заинтересованная в лояльности депутатского корпуса, признал, что именно председатель легислатуры «дает список членов собрания».

В-пятых, третье место во властной иерархии вслед за главой городского округа и председателем гордумы, судя по всему, занимает нынешний заместитель главы городского округа, бывший глава администрации города. Ранее он был на многих важных постах в локальном сообществе и в принципе мог бы претендовать на должность главы городского округа. Так считали многие респонденты, в т. ч. сам председатель городской думы: «Это самый порядочный чиновник из тех, которых я знаю». Однако возникает вопрос: почему в таком случае он не стал главой городского округа? Наши респонденты объясняли это отсутствием у него серьезных политических амбиций. «В отличие от главы городского округа он не лезет в политику вообще, занимается чисто хозяйством. Но он реальная фигура. Он - фигура, которая бы устроила, наверное, всех» (эксперт, бывший заместитель главы районной администрации Y).

Таким образом, спустя восемь лет расклад сил в ядре локальной элиты, как и раньше, может быть обозначен как триумвират, но это уже триумвират другого качества, в котором все три фигуры обладали необходимыми лидерскими качествами со сформированным ядром команды. Его отличие от предыдущего заключается в изменившихся отношениях между акторами. В период проведения первого этапа исследования между городской и районной структурами власти наблюдались постоянные трения, а конфликт по поводу реформы муниципальной власти открыто обсуждался в публичном пространстве. Тогда имела место связка «город-завод», которой в определенном смысле противостояла районная власть. Во время второго этапа исследования все три наиболее влиятельных актора, по сути, находились в единой команде: между ними не было сколь-нибудь серьезных конфликтов, им уже не противостояли солидные оппоненты, каким ранее было руководство района, а политические баталии в публичной сфере имели очень ограниченный характер и, по сути, проявлялись только в период выборов.

Все это в целом способствовало лидерству главы города (особенно в случае расширения команды своих последователей). Тот факт, что региональные власти готовы помогать городу, дает возможность предположить, что сложившийся расклад сил и лидерский потенциал главы позволят обеспечить выход территории из кризиса, обусловленный свертыванием деятельности градообразующего предприятия. Наличие в городе двух других лидеров существенно усиливает лидерские ресурсы самого главы до тех пор, пока фигуры, входящие в триумвират, действуют в унисон. Можно допустить, что данная конфигурация лидеров способствует повышению эффективности управления, но только до тех пор, пока лидеры сохраняют неконфликтный уровень взаимодействия друг с другом. 


\section{Город Z: возвращение во власть}

В городе Z лидерство и власть в периоды и первого, и второго этапов нашего исследования в целом соответствовали традиционному паттерну. Наиболее влиятельным локальным актором являлся руководитель городской администрации. Это было бесспорно в период проведения первого этапа, и это же обозначилось в период второго этапа (после ее повторного назначения главой города). Именно последнее обстоятельство - возвращение бывшего руководителя города на свой пост спустя три года после увольнения - стало главной особенностью политической жизни города Z.

Из всех рассмотренных нами кейсов доминирование главы администрации города $\mathrm{Z}$ в период первого этапа исследования было, пожалуй, наиболее очевидным. Это не только признавали все наши респонденты, но и она сама в этом нисколько не сомневалась: «Может быть, я покажусь нескромной, но на сегодня я являюсь самой влиятельной фигурой в городе. Даже рядом я никого не вижу. Я считаю, что власть должна быть сильной».

С чем связано такое единодушие? В городе $Z$ высокий властный потенциал позиции главы администрации был в полной мере реализован благодаря наличию у инкумбента определенного набора умений и связей. Солидный пул персональных ресурсов: личные качества, опыт работы, мотивация, знания, особенно в области финансов, прагматические связи с субъектами власти более высокого уровня, умение обеспечивать внешнее финансирование города и включать его в федеральные программы - все это обеспечивало широкие возможности влияния в различных сферах локальной политики и управления. Не менее важным ресурсом влияния глава администрации считала свою любовь к городу, преданность делу и умение добиваться поставленных целей. Именно эти качества, судя по всему, сыграли решающую роль в ее возвращении.

Однако, признавая высокий уровень профессиональных компетенций главы администрации, наши респонденты в период проведения первого этапа исследования указывали и на ряд отрицательных личных качеств, среди них - деление на «своих» и «чужих», фаворитизм, авторитарный стиль управления ( Я за авторитаризм. Иначе ничего не добьешься»), стремление полностью контролировать ситуацию. Респонденты также полагали, что причиной ее снятия с должности стала неправильная позиция по отношению к губернатору, который был назначен незадолго до этого («он мне пока не интересен»), и то, что она даже допускала возможность в случае необходимости вступить с ним в открытую конфронтацию. Ее самоуверенность в конце концов привела к отставке, причину которой четко выразил заместитель губернатора: «Я не могу позволить такой роскоши - иметь главу администрации города, который не уважает региональные власти, поскольку это большой риск».

В тот момент мы были уверены, что политическая карьера главы администрации закончилась, но мы ошиблись: новый губернатор возвратил ее на прежнее место. Главной причиной ее возвращения стала неудовлетворительная деятельность ее сменщика-«варяга» («город, когда был этот глава, ничего хоромего не получил»). При этом его реальное влияние и политический вес оказались на порядок ниже («прежний глава не обладал влиятельностью в городе, несмотря на то, что 
он возглавлял исполнительную власть. Он как-то сразу потерял позиции. Вот вам и роль личности. Ему личностного ресурса просто не хватило»), и он не воспринимался респондентами как наиболее влиятельный актор в локальном сообществе. Представители городской элиты подчеркивали, что «он не любил и не понимал город», «не смог выстроить коммуникацию ни с элитами, ни с населением». В результате все основные локальные акторы, в т. ч. директора, предприниматели и депутаты, обратились к губернатору с просьбой о его замене. Время нахождения этого человека во власти до сих пор воспринимается как «потерянное время» для города.

Но почему вернули именно еe, а не нашли нового главу города? Одна из причин состояла в несогласии некоторых фигур в руководстве области со снятием ее с поста несколько лет назад. Другая причина заключалась в том, что «скамейка запасных “выюжена”. Выбирать становится не из кого. "Все карты крапленые и замусоленныее” (известный журналист). Наконец, при всех своих недостатках, она - «достаточно эффективный руководитель. В городе при ее руководстве многое было сделано» (вице-губернатор, курировавший город в период ее пребывания у власти).

Первые шаги старого/нового главы после возвращения пока не позволяют сделать однозначные выводы о том, будет ли она руководить в том же стиле, как и в свой первый срок. По мнению большинства респондентов, она стала более гибкой; и она сама уже не считает себя, как было ранее, наиболее влиятельной фигурой в городской политике; при этом она признает необходимость внести коррективы в свой стиль управления: «Отношение к жизни и клюдям у меня изменилось. Я стала мягче относиться к людям и к их недостаткам. Мне большой опьт дали духовные наставники».

Вернувшись на должность, старый/новый глава начала со строительства команды и вернула часть ее бывших членов. Но на момент интервью добиться эффективной работы новой команды, по ее признанию, пока не удалось: «Команда была мной по возвращуению частично восстановлена, после того как ее "зачистил” прежний глава. В нее вернулись три человека, но сегодня им не хватает темпа. Я просто натыкаюсь на стену непонимания. Сейчас этот маховик раскрутился, и они значительно ускорились, но пока недостаточно».

Не менее важным условием успешной деятельности руководителя города являются хорошие отношения с губернатором и его командой. В этом плане ситуация у вновь назначенного главы гораздо более благоприятная, чем она была в период проведения первого этапа исследования. В отличие от предыдущего губернатора и его команды, с которыми отношения не сложились, нынешний губернатор ее активно поддерживает. При этом стратегии и модели поведения нового губернатора в отношении муниципалитетов изменились в сторону некоторого расширения автономии местных руководителей. «Мне кажется, что сегодняшняя губернаторская модель взаимодействия ближе к экспертной. Доминирования и контроля нет, как и давления〉 (бывший председатель городского совета). Со своей стороны старый/новый глава характеризует нового губернатора только положительно: «Он не просто меня вернул, он мне озвучил иели. Мне с ним очень интересно. Мы с ним на одной волне, мыслим одними категориями».

Таким образом, в городе $\mathrm{Z}$ удалось восстановить лидерство, и можно предположить, что в перспективе ситуация в городе будет улучшаться, если главе 
городской администрации удастся сохранить лояльность губернатора, отказаться от давления на свою элиту и завершить формирование новой команды. Позитивные ожидания элит относительно старого/нового главы города связаны именно с тем, что ей удастся переломить существующую негативную ситуацию в городе и повысить эффективность городского управления.

\section{Лидерство и власть в локальных сообществах: общее и особенное}

В настоящее время позиция руководителя исполнительной власти в городе, как показывают эмпирические исследования (см., например, [Витковская, Рябова 2011]), дает ее обладателям наибольший формальный и неформальный потенциал власти. Однако статус главы города сам по себе еще не гарантирует лидерства в локальном сообществе. Далеко не все руководители изученных нами городов были успешны как в обладании достаточной властью и авторитетом, возможностями реализовать свою волю внутри локального сообщества («власть над»), так и в достижении коллективных целей сообщества («власть для»). Наиболее наглядные примеры - глава города $\mathrm{X}$ и снятый с должности по инициативе местной элиты «варяг» в городе Z.

Успех или неуспех в деятельности первого лица городского сообщества и его эффективность во многом зависят от его персональных ресурсов: личностных качеств, профессионализма, значимых для деятельности связей и отношений с другими влиятельными акторами и с населением. Разный арсенал персональных ресурсов в наибольшей степени предопределяет специфику власти и лидерства в локальных сообществах; смена руководителей, как показывают эмпирические результаты, существенно меняла паттерны власти и лидерства, несмотря на сложную социально-экономическую ситуацию, и это имело место во всех изученных нами городах.

В тех случаях, когда персонального ресурса явно не хватало, вакуум власти заполнялся иными силами. Слабость руководителей исполнительной власти города, отсутствие у них лидерских качеств компенсировались либо другими локальными акторами (бывшим главой администрации в городе X с помощью «удаленного управления»), либо региональными властями, усиливавшими контроль с целью поддержания порядка и управляемости территории (в городе $\mathrm{Z}$ после отставки нынешнего главы города).

Исследование показало, что муниципальные структуры надежно встроены во властную вертикаль; поэтому у всех субъектов локальной власти был относительно ограниченный коридор возможностей, однако они должны были постоянно учитывать, что «губернатор в городе может абсолютно все». При этом акторы регионального уровня включались в пространство локальной политики только в случае явной необходимости или по инициативе местных властей [Чирикова, Ледяев 2013, Ledyaev, Chirikova 2019]. Поэтому соблюдение устоявшихся правил взаимоотношений с региональными властями становится условием сохранения относительной автономии локальных лидеров.

Стабильность положения и успешность деятельности руководителей города зависят не только от выстроенных отношений с региональными властями, 
но и от поддержки локальных элит. Претензия на лидерство и поступательное развитие требуют слаженной работы руководителя и его команды - самых важных последователей лидера. Исследование показывает, что изменения в составе команды (как позитивные, так и негативные) обусловливают и соответствующие изменения в эффективности управленческого процесса. Материалы исследования полностью подтверждают правомерность известной истины «короля играет свита». Наиболее наглядно это проявилось в снижении авторитета и эффективности деятельности бывшего главы города X после ухода ряда ключевых фигур из его команды, в слабости его сменщика, фактически оставшегося без команды.

Чем же обусловлены различия в паттернах и конфигурациях лидерства и власти между городами? Какие факторы вызывают в них наибольшие изменения? Прежде всего институциональные реформы в структуре муниципальной власти: так, в двух малых городах одного из исследованных регионов существенное влияние на конфигурацию лидеров оказал процесс слияния городской и районной структур власти. В результате вместо двух потенциальных лидеров локального сообщества остался один, что изменило и расклад сил, и характер взаимоотношений внутри городской элиты. Структурные реформы уже стимулировали существенные изменения в ядре локальной элиты города Y, сделав это ядро более монолитным. Аналогичный процесс в настоящее время запущен в городе X.

Существенно влияет на паттерны власти и лидерства и смена губернатора. Несмотря на то, что вертикаль власти, выстроенная президентом В.В. Путиным, усиливает унификацию региональных политических практик и роль федерального центра в формировании региональной политики, модели взаимоотношения региональной и локальной структур власти традиционно зависят от лидеров регионов. «Смена первого лица всегда ведет к смене общественной и политической парадигмы в регионе. Она не может не меняться с приходом нового губернатора, и это вряд ли кто-то будет оспаривать, кто разбирается в элитном раскладе сил〉. Эту мысль, высказанную известным региональным журналистом, разделяют и другие наши респонденты.

Смена губернаторов, имевшая место в обоих регионах, повлияла и на состав лидерского пула (возвращение во власть бывшего главы в городе Z, назначение главы района X на должность сначала главы города, а через некоторое время и главы городского округа, блокируемое прежним губернатором), и на взаимоотношения между властями региона и города. Последние определяются прежде всего характером и стилем контроля региональных чиновников над деятельностью руководителей городов. В этом плане модель взаимоотношений между региональными и городскими властями в одном из исследованных регионов, судя по всему, несколько изменилась в сторону некоторого расширения автономии местных руководителей.

Исследование показало, что различия в эффективности и качестве управления в изученных нами городах едва ли не в наибольшей степени зависят от лидерских качеств и связей руководителей города: именно персональный фактор «делает разницу». Обладая примерно одинаковыми полномочиями, руководители городов имели разный политический вес в своих локальных сообществах. Лидерство, авторитет, легитимность, команда последователей, поддержка региональных властей и населения - все это важнейшие основания эффективной деятельности 
руководителей города на своем посту. Показательна в этом плане динамика лидерства главы администрации в городе $\mathrm{X}$, которая шла по нисходящей от первого ко второму сроку своего пребывания в должности. Иной характер имело развитие ситуации в городе Z, где новому/старому главе города пришлось фактически заново формировать свой авторитет и арсенал влияния.

Наконец, на лидерство и власть в локальных сообществах существенно воздействуют ситуативные факторы: например, в городе Y значительное влияние на конфигурацию власти и лидерства оказало изменение формы включенности градообразующего предприятия в локальный политический процесс. В результате директор предприятия перестал быть одним из публичных лидеров городского сообщества; в то же время «серый кардинал», получивший высокий пост председателя городской думы, стал одним из публичных лидеров, соединив воедино формальные и неформальные ресурсы.

Какие конкретные различия в структуре власти и лидерства были выявлены? Наиболее очевидное различие между городами оказалось по числу топ-лидеров. В городах Z и X в период проведения первого этапа исследования четко выделялся один локальный лидер, явно возвышавшийся над другими элитными фигурами (моноцентричная структура власти); в то же время в городе Ү и на первом, и на втором этапах были обнаружены своеобразные триумвираты наиболее влиятельных акторов - три фигуры с сопоставимыми ресурсами власти и влияния в локальном сообществе (полицентричная структура власти).

Различными оказались и властный ресурс лидеров (руководителей), степень их доминирования в локальном политико-управленческом пространстве. Хотя вряд ли есть возможность адекватно измерить и сравнить величину и объем власти субъектов, находящихся в разных локальных сообществах, все же можно уверенно утверждать, что в период проведения первого этапа исследования наибольший потенциал навязывания своей воли имели главы городов $\mathrm{Z}$ и $\mathrm{X}$, где сформировались моноцентричные структуры власти. И наоборот, наименьшим потенциалом власти обладали снятый по требованию элит глава города Z и слабый глава города Х. Более сбалансированная структура власти имела место в городе Y, где и на первом, и на втором этапах исследования не прослеживалось явного доминирования одного актора, а каждый из трех топ-акторов имел свои зоны влияния.

Лидерство, как и другие социальные явления, находится в процессе постоянного изменения. Исследование демонстрирует динамику лидерства глав не только при смене ключевых фигур, но и в результате эволюции лидеров, изменений в их установках, формах и методах взаимодействия с окружающими. Наиболее наглядный пример - изменившийся паттерн лидерства главы города $\mathrm{Z}$ после ее второго прихода к власти; другой пример - снижение авторитета и влияния в период своего второго срока пребывания в должности главы города X.

Отношения между наиболее влиятельными акторами в малых городах также варьировались по степени конфликта/единства между ними. В городе Ү отношения внутри триумвирата существенно различались в разные временные периоды: во время первого этапа исследования в городе сложилась режимная коалиция «руководство города / руководство завода», которой противостояла команда главы администрации района. Между ними сложились довольно сложные отношения, периодически обострявшиеся в периоды выборов. В период проведения второго 
этапа исследования новый триумвират уже представлял собой фактически одну команду, и между акторами не было серьезных противоречий.

Все ли упомянутые нами персоны могут считаться лидерами городских сообществ? В нашем случае сомнение в статусе лидера было только относительно недавно снятого главы в городе X и «варяга» в городе Z, который ушел с должности по требованию городского сообщества. Их управление нельзя было назвать эффективным, что подтверждается оценками элит, и это в конечном счете привело к разрушению их политической карьеры.

\section{Заключение:}

муниципальная власть нуждается в лидерах

Результаты исследования подтверждают предположение о том, что не всегда руководители исполнительной власти являются наиболее влиятельными фигурами в городском сообществе (хотя потенциально и обладают наиболее значимыми формальными ресурсами), поскольку сами по себе ресурсы еще не являются гарантией лидерства и эффективного управления городом. При этом не все руководители администраций в изученных городах реально были лидерами локальных сообществ, поскольку у них не было достаточной власти, авторитета, полноценной команды и надежных последователей.

Между тем именно наличие/отсутствие сильных лидеров в социуме часто «делает разницу». Несмотря на то, что вертикаль власти окончательно выстроена и муниципальные структуры стали ее частью, смена фигур во власти может существенно скорректировать не только стиль управления и характер внутриэлитных взаимоотношений, но и властную иерархию. Более того, как показывает ситуация в городе Z, даже персональная эволюция локальных лидеров может привести к существенным изменениям как в их политических стратегиях, так и в балансе власти в локальном сообществе, причем даже акторы с высоким ресурсным потенциалом должны постоянно подтверждать претензии на лидерство.

Результаты исследования подтвердили наши гипотезы. Оценки, полученные в ходе интервью, свидетельствуют о том, что командный ресурс главы во многом обусловливает его лидерский потенциал, который в свою очередь определяет эффективность управления городом. Ситуации с главами-антилидерами наглядно демонстрируют, как отсутствие у них необходимых качеств приводит к росту проблем, а их неспособность сформировать и/или сохранить команду последователей еще сильнее сужает возможности для изменения ситуации в городе.

Результатами исследования подтверждена и вторая гипотеза: лидер, хотя и не способен полностью переломить негативные тенденции, обусловленные внешними факторами, все же имеет возможности смягчить их последствия. Ухудшение социально-экономической ситуации в малых городах может быть приостановлено в случае исполнения главой города и других представителей элитного пула лидерских функций и использования их для достижения общего блага.

Кроме этого, исследование продемонстрировало значимость роли лидеров локальных сообществ в периоды кризисов и институциональных реформ. Когда возникают трудности, неизбежно формируется запрос на лидерство, поскольку 
руководители предлагают свое видение ситуации, свежие подходы к решению проблем, способность мобилизовать социум на их реализацию, и сегодня запрос на эффективное лидерство в российских локальных сообществах становится все более отчетливым.

\section{Литература}

Витковская Т., Рябова О. (2011) Моногорода Среднего Урала: локальные элиты и политические процессы. Екатеринбург: РИО УРО РАН.

Красильщиков Г., Троицкая Е. (2018) Динамика межэлитных взаимоотношений на локальном уровне (на примере аграрного муниципального района Пермского края) // Ars Administrandi (Искусство управления). Т. 10. № 2. С. 319-334.

Ледяев В. (2001) Власть: концептуальный анализ. М.: РОССПЭН.

Ледяев В. (2012) Социология власти. М.: ВШЭ.

Панов П. (2019) Городские думы малых и средних городов Свердловской области: потенциал автономии в отношениях с главой города // Вестник Пермского федерального исследовательского центра. № 3. С. 95-107.

Пустовойт Ю. (2019) Как создается режим: властные коалиции в сибирских городах // ПОЛИС. № 4. С. 104-118.

Сельцер Д. (2017) Рекрутирование локальной административной элиты России: исходные данные для построения системно-динамической модели // Pro Nunc. № 2. C. 27-32.

Чирикова А.Е., Ледяев В.Г. (2013) Губернатор и его команда в пространстве городской политики малых российских городов // Вестник Пермского университета. № 3. C. 4-25.

Чирикова А., Ледяев В. (2017) Власть в малом российском городе. М.: ВШЭ.

Чирикова А., Ледяев В., Сельцер Д. (2014) Власть в малом российском городе: конфигурация и взаимодействие основных акторов // ПОЛИС. № 2. С. 88-105.

Шкель С. (2017) Рекрутирование локальных элит в условиях субнационального авторитаризма: опыт Республики Башкортостан // Политическая наука. № 4. С. 137-160.

Burns J.M. (1978) Leadership, New York: Harper and Row.

Copus C., Leach S. (2014) Local Political Leaders // The Oxford Handbook of Political Leadership (eds. Rhodes R.A.W., 't Hart P.), Oxford: Oxford University Press.

Geddes B. (1994) Politician's Dilemma: Building State Capacity in Latin America, Berkeley: University of California Press.

Greasley S., Stoker G. (2009) Urban Political Leadership // Theories of Urban Politics (eds. Davies J., Imbroscio D.), London: Sage.

Harding A. (2009) The History of Community Power // Theories of Urban Politics (eds. Davies J., Imbroscio D.), London: Sage.

Hlynsdottir E.M. (2016) Leading the Locality: Icelandic Local Government Leadership Dilemma // Lex Localis - Journal of Local Self-Government, vol. 14, no 4, pp. 807-826.

Ledyaev V., Chirikova A. (2019) Governors and Local Elites in Russia: Patterns of Interaction // European Politics and Society, vol. 20, no 3, pp. 315-332.

Lijphart A. (1975) The Comparative-cases Strategy in Comparative Research // Comparative Political Studies, vol. 8, no 2, pp. 158-177.

Stogdill R.M. (1974) Handbook of Leadership, New York: The Free Press.

Stone C. (1995) Political Leadership in Urban Politics // Theories of Urban Politics (eds. Davies J., Imbroscio D.), London: Sage.

't Hart P. (2014) Understanding Public Leadership, Basingstoke: Palgrave Macmillan.

't Hart P., Rhodes R.A.W. (2014) Puzzles of Political Leadership // The Oxford Handbook of Political Leadership (eds. Rhodes R.A.W., 't Hart P.), Oxford: Oxford University Press.

Wrong D.H. (2002) Power. It's Forms, Bases, and Uses, New Brunswick, London: Transaction Publishers. 


\title{
Leadership and Power in a Small Russian Town
}

\author{
A. CHIRIKOVA*, V. LEDYAEV**
}

\begin{abstract}
*Alla Chirikova - DSc in Sociology, Chief Researcher, Institute of Sociology of the Federal Center of Theoretical and Applied Sociology of the Russian Academy of Sciences. Address: 24/35, bldg 5, Krzhizhanovskogo St., Moscow, 117218, Russian Federation. E-mail: chirikova_a@mail.ru

**Valeri Ledyaev - DSc in Philosophy, Professor, Faculty of Social Sciences, National Research University Higher School of Economics. Address: 20, Myasnitskaya St., Moscow, 101000, Russian Federation. E-mail: vledyaev@hse.ru
\end{abstract}

Citation: Chirikova A., Ledyaev V. (2021) Leadership and Power in a Small Russian Town. Mir Rossii, vol. 30, no 1, pp. 29-48 (in Russian). DOI: 10.17323/1811-038X-2021-30-1-29-48

\section{Abstract}

This article presents the findings from an empirical study of leadership and power in three small towns in Perm Krai and Ivanovo Region, conducted in 2011-2015 and 2018-2019.

The study shows that despite the centralization policy pursued by the federal center and the structured power vertical, there remains a wide variability of the patterns of power and leadership, due mainly to personal factors. We found both monocentric configurations of power (one local leader clearly stood out), and a polycentric power structure (alliances and/or rivalry of several actors with comparable power and influence). A change in the configuration of power actors can significantly influence not only the style of management and the nature of intra-elite relationships, but the power hierarchy as well.

Leadership, like other social phenomena, is always in the process of change. The dynamics of power and leadership are most influenced by institutional changes in the structure of municipal government, new regional leaders, personal and situational factors. The outcomes of the study confirm the assumption that the heads of the executive branch are not always the most influential figures in a community, although they have the most significant formal resources of power. Not all heads of administrations in the towns we studied were actually the leaders of local communities, since they did not have sufficient authority, a strong team, or well-built relations with regional authorities. In cases where there was clearly not enough personal resources, the power vacuum was filled by other forces - either by other local actors or by regional authorities, strengthening control to maintain the order and manageability of the territory.

The study has shown that a leader, although unable to completely reverse negative tendencies due to external factors, can mitigate their consequences. The deterioration of the socio-economic situation in small towns can be halted if the heads of towns and other representatives of the elite pool are able to take on leadership functions and use them to achieve the common good. In times of crisis and institutional reform, the role of leaders increases. Therefore, when difficulties arise, a demand for leadership is formed.

Keywords: power, leadership, heads of the town, small towns, local government, effectiveness of government 


\section{References}

Burns J.M. (1978) Leadership, New York: Harper and Row.

Chirikova A., Ledyaev V. (2013) Gubernator i ego komanda v prostranstve gorodskoj politiki [Governor and His Team in Urban Politics of Small Russian Towns]. Vestnik Permskogo universiteta, no 3, pp. 4-25.

Chirikova A., Ledyaev V. (2017) Vlast'v malom rossijskom gorode [Power in a Small Russian Town], Moscow: HSE.

Chirikova A., Ledyaev V., Seltser D. (2014) Vlast' v malom rossijskom gorode: konfiguratsiya i vzaimodejstvie osnovnikh aktorov [Power in a Small Russian Town: Configuration and Interaction of the Main Actors]. POLIS, no 2, pp. 88-105.

Copus C., Leach S. (2014) Local Political Leaders. The Oxford Handbook of Political Leadership (eds. Rhodes R.A.W., 't Hart P.), Oxford: Oxford University Press.

Geddes B. (1994) Politician's Dilemma: Building State Capacity in Latin America, Berkeley: University of California Press.

Greasley S., Stoker G. (2009) Urban Political Leadership. Theories of Urban Politics (eds. Davies J., Imbroscio D.), London: Sage.

Harding A. (2009) The History of Community Power. Theories of Urban Politics (eds. Davies J., Imbroscio D.), London: Sage.

Hlynsdottir E.M. (2016) Leading the Locality: Icelandic Local Government Leadership Dilemma. Lex Localis - Journal of Local Self-Government, vol. 14, no 4, pp. 807-826.

Krasilschikov G., Troitskaya E. (2018) Dinamika mezhelitnykh vzaimootnoshenij na lokal'nom urovne (na primere agrarnogo munitsipal'nogo rayona Permskogo kraya) [Dynamics of Inter-elite Relations at the Local Level (The Case of the Agrarian Municipal District of Perm Territory)]. Ars Administrandi, vol. 10, no 2, pp. 319-334.

Ledyaev V. (2001) Vlast': kontseptual'nyj analiz [Power: A Conceptual Analysis], Moscow: ROSSPEN. Ledyaev V. (2012) Sotsiologiya vlasti [Sociology of Power], Moscow: HSE.

Ledyaev V., Chirikova A. (2019) Governors and Local Elites in Russia: Patterns of Interaction. European Politics and Society, vol. 20, no 3, pp. 315-332.

Lijphart A. (1975) The Comparative-cases Strategy in Comparative Research. Comparative Political Studies, vol. 8, no 2, pp. 158-177.

Panov P. (2019) Gorodskie dumi malikh i srednikh gorodov Sverdlovskoj oblasti: potential avtonomii v otnosheniyakh s glavoj goroda [Town Councils of Small and Medium-sized Towns of the Sverdlovsk Region: The Potential of Autonomy in Relations with the Head of the Town]. Vestnik Permskogo federal'nogo issledovatel'skogo tsentra, no 3, pp. 95-107.

Pustovoit Yu. (2019) Kak sozdaetsya rezhim: vlastnie koalitsii v sibirskikh gorodakh [How the Regime Is Formed: Power Coalitions in Siberian Towns]. POLIS, no 4, pp. 104-118.

Seltser D. (2017) Rekrutirovanie lokal'noj administrativnoj elity Rossii: iskhodnye dannye dlya postroeniya sistemno-dinamicheskoj modeli [Recruiting of the Local Administrative Elites in Russia: Initial Data for Building a System-dynamic Model]. Pro Nunc, no 2, pp. 27-32.

Shkel' S. (2017) Rekrutirovanie lokal'nikh elit v usloviyakh subnatsional'nogo avtoritarisma: opit respubliki Bashkortostan [Recruiting Local Elites in the Context of Subnational Authoritarianism: The Experience of the Republic of Bashkortostan]. Politichaskaya nauka, no 4, pp. 137-160.

Stogdill R.M. (1974) Handbook of Leadership, New York: The Free Press.

Stone C. (1995) Political Leadership in Urban Politics. Theories of Urban Politics (eds. Davies J., Imbroscio D.), London: Sage.

't Hart P. (2014) Understanding Public Leadership, Basingstoke: Palgrave Macmillan.

't Hart P., Rhodes R.A.W. (2014) Puzzles of Political Leadership. The Oxford Handbook of Political Leadership (eds. Rhodes R.A.W., 't Hart P.), Oxford: Oxford University Press.

Vitkovskaya T., Ryabova O. (2011) Monogoroda Srednego Urala: lokal'nye elity i politicheskie protsessi [Monotowns of the Middle Urals: Local Elites and Political Processes], Yekaterinburg: RIO URO RAN.

Wrong D.H. (2002) Power. It's Forms, Bases, and Uses, New Brunswick, London: Transaction Publishers. 